\title{
Bauhaus now! Design and performative strategies
}

\section{Thea Brejzek \& Christof Mayer}

To cite this article: Thea Brejzek \& Christof Mayer (2019) Bauhaus now! Design and performative strategies, Theatre and Performance Design, 5:1-2, 75-95, DOI: 10.1080/23322551.2019.1593618

To link to this article: https://doi.org/10.1080/23322551.2019.1593618

\section{Published online: 24 May 2019.}

Submit your article to this journal

WII Article views: 4

View Crossmark data $\asymp$ 


\title{
Bauhaus now! Design and performative strategies
}

\author{
Thea Brejzek ${ }^{a}$ and Christof Mayer ${ }^{b}$ \\ ${ }^{a}$ Faculty of Design, Architecture and Building, University of Technology Sydney, Sydney, Australia; \\ ${ }^{b}$ raumlaborberlin/Bergen University, Berlin, Germany
}

\begin{abstract}
Built around four case studies of intensive design studios, led by the authors and several collaborators at the Bauhaus Dessau with Interior Architecture and Architecture students from Sydney and Berlin between 2015 and 2018', this article asks whether and how, not only the architecture and design produced at the historic Bauhaus but also its pedagogical legacy can be made relevant for today's design education. In particular, it outlines and argues for the value of performative strategies being developed and utilized in studio teaching when working from a historical precedent as a means to activate interior space through bodily action and thus transport the Bauhaus spirit of living and working together into the here and now.
\end{abstract}

\section{Introduction}

Every year, the Bauhaus Foundation Dessau invites universities to conduct design studios with a particular view to the development of new and innovative pedagogical methods. Studios are centered around the Bauhaus' annually changing 'keywords' or themes such as movement, standards, collective - that refer to its history but that are equally relevant in today's design and design education discourse. The overall programe, entitled Bauhaus Open Studios, attracts educators and design students internationally who respond to the given provocation in one to two-week intensive studios held on the premises of the former school building. What drew the authors (termed ' $w e^{\prime}$ in the following), with backgrounds in performance, design, and architecture to embrace this opportunity was in the first instance the fact that the Bauhaus was both political and visionary in its aim to change everyday life through design for many. In its short existence between 1919 and 1933, the historic Bauhaus operated as a pathbreaking laboratory of the future through its studio-based 'workshops of modernity' (MoMA2009/2010) in all areas of art, design, and architecture. It was the aim of the Bauhaus to transform every aspect of daily life towards the creation of a 'new man, a new city, a new world' and within its fourteen years of existence, the Bauhaus set in motion a democratization of design that is reflected today in all aspects of the objects we use and the spaces we live in. In this ambition, articulated in objects and buildings, as much as in performances, choreographies, textiles, and paintings, texts and manifestos, seemed to us to lie distinct links to today's concerns with regard to design education and the role of the designer in society. We 
identify these links as a designers' engagement with the concept of minimal living and design for manufacture that fosters and enables a democratization of design, i.e. that produces functional and affordable design for everyday use. Today, as academia and industry are challenged to critically reflect on the role of design and the designer in a rapidly changing urban environment, amidst dramatic environmental concerns, and, for design to redefine itself as social design, that is, as design for society, a critical engagement with Bauhaus principles can serve to underline its potentiality towards responsible and sustainable fabrication and distribution processes. However, at the historic Bauhaus, attention was given to not only the products that designers developed and produced, and to a pedagogy that emphasized interdisciplinarity and collaboration, but also to the physical spaces in which what we might call a 'deep learning' today, happened. In Dessau particularly, close working and living relationships between Bauhaus masters and students were fostered with the Prellerhaus as student accommodation that was part of the Bauhaus building complex and the short distance between school building, student accommodation and the masters' private residencies.

Performative practices such as the iconic Bauhaus parties ${ }^{2}$ played a significant role in the Bauhaus' overall activities from its inception and, understood as a social and pedagogical component in the Bauhaus philosophy, further fostered the exchange between masters and students with invitations often extended to the general population. New materials and technologies were used in party costumes and, significantly, by Oskar Schlemmer in his Triadic Ballet (Stuttgart 1922/Weimar 1923) where man and technology were merged in sculptural, ungendered and futuristiclooking figurines.

Considering Bauhaus pedagogies, design principles and methods, its social organization and activities as outlined above, the authors conceptualized four design studios over four years that engaged with contemporary concerns regarding the way we live together today and linked these with 'precedents' from the historic Bauhaus. And while the term precedent is correct, it does not quite capture in its neutrality what we were after. Rather, the historical precedents in the form of buildings, photographs, texts and plans, acted as catalysts and provocations for the students' individual and group design journeys. Students were to live in the Prellerhaus and work in the class rooms of the former school building and adjacent workshops. The studios' formal structure was to be a performative 'Design and Build' in that parts of the overall design outcome were to be full-scale installations that enabled a spatial performance by enabling interaction between actor and built structure. Beyond the final, built result, however, we regarded the action of building together as a performative action in itself. This, we decided, was best to happen during either the first or second week whereas the respective other week was to be dedicated to research and site visits, and as a consequence, the studio's location was split between the Bauhaus Dessau and raumlaborberlin's ${ }^{3}$ headquarters in Berlin. In this way, Berlin provided the contemporary anchor point and Dessau the historical one.

\section{Live Conditions!/collective (2015)}

During two weeks in July 2015, this studio explored speculative conditions for minimal living beyond functional and technical issues and limitations. The studio looked at notions of inhabitation and dwelling as psychological desires and states and critiqued 
these concepts to trigger a design process that reframed basic needs beyond the cliched notion of the 'shelter'. The main focus was the displaced and stateless situation of refugees today as one of the major global challenges. One of raumlaborberlin's current projects, a refugee integration project located in a former plant nursery seemed a fitting context in which we could embed the students for the first studio week. The Bauhaus theme of 2015, Collective, led us to consider the historical figure of the architect Hannes Meyer, the second Bauhaus director after Gropius, who was committed to the cooperative movement ${ }^{4}$ and his manifesto 'The New World' from 1926, as a central text for the second studio week in Dessau. In 'The New World', Meyer stresses that 'Co-operation rules all the world. Community rules over individual being.' The text is supported by several photographs that represented new technologies and the concepts behind them. Amongst these rather typological images is an unusual image by Meyer titled the Co-op. Interieur. The photograph's setting suggests that it was staged for the purpose of demonstrating Meyer's theses of what is needed for minimal living, namely the standard product that to him is a prerequisite for social equity Figure 1.

Co-op. Interieur shows some of the standard products named in the manifesto - the gramophone as one of the new media for information and as a propaganda machine, and the folding chair, both extended and in its folded position fixed to the wall, and adds others - a bed base, a round folding table and a wall shelf with spice glasses - making the image a symbolic demonstration of his political philosophy rather than a concrete example of future living.

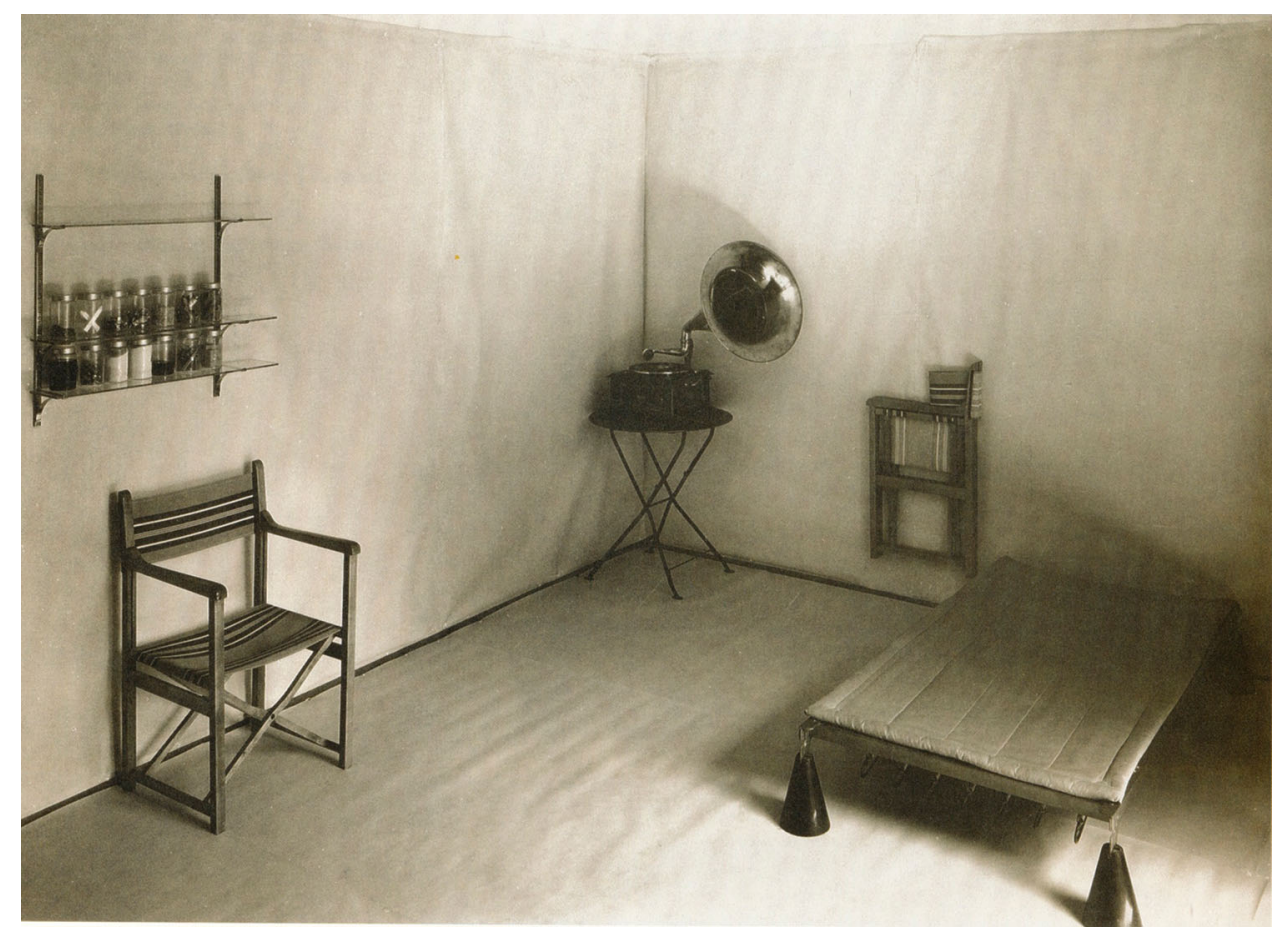

Figure 1. Co-op. Interieur (Hannes Meyer 1926). 


\section{Meyer writes}

The city is the most manifold biological agglomeration that people have to master consciously and constructively form. The demands we make of modern life, either in general or by respective social standing, are of the same sort. The truest mark of community is the gratification of such needs by equivalent means. The result of such collective demands is the standard product. Typical standard wares of international origin and uniformity are: the folding chair, the rolltop desk, the light bulb, the bathtub, the portable gramophone. They are the instruments of mechanization in our daily life. Their standardized form is impersonal. Their manufacture proceeds serially (Meyer 1994, 445-48).

The furniture items shown in Co-op. Interieur present as props arranged as if on a stage set made from a paper floor and paper walls and awaiting its inhabitant, the transient man of the new world. Meyer's engagement with the Co-op propaganda theater (1924) where he was dramatist, set designer and director in one ${ }^{5}$, is evident in this image where the effect on the viewer is clearly planned. Meyer positions the gramophone in the center perspectival line where the two side walls meet as the most potent symbol of this new world. Man's basic living needs such as rest, social exchange and nourishment are symbolized with the bed, the two chairs and the shelf with the spice jars.

The studio used Meyer's Co-op. Interieur photograph as the central reference for a contemporary visual manifesto during the second week of the studio on site at the Bauhaus Dessau. Students were asked to reinterpret Meyer's programmatic and propositional interior and to build their reimagined Co-op. Interieur in full scale and in materials of their choice. They were then asked to photograph their interior and this photograph, rather than the model itself was the outcome. However, the students' encounter with Meyer's photographic mise en scène occurred only after they had spent week one of the studios in an embedded research situation with five refugees from Mali who were participants in the so-called Gärtnerei (plant nursery) project in Berlin. Located on a deconsecrated cemetery close to the former Tempelhof airport the 'Gärtnerei' is a refugee project initiated by the cultural center 'Schlesische 27 ' and raumlaborberlin and supported by the Berlin City Cultural Fund, the Protestant Cemetery Association Berlin Mitte and IKEA Foundation. Being still in the booster phase in 2015 and still ongoing as this article goes to press, the project offered improvised spaces for learning, working and meeting placed in a vacant building and unused areas of the cemetery. Artists, architects and young refugees in the meantime have set up a nursery workshop where refugees teach their newly acquired skills to the general population Figure 2 .

German language classes as well as garden and landscape design are taught and a communal kitchen sits at the heart of the complex. The Gaertnerei was meant to be a lowthreshold blueprint for social transformation where the politically charged topic of refugees is de-escalated in a relaxed social interaction between residents and recently arrived refugees. Students conducted informal interviews with the refugees and roundtable discussions throughout three days in the improvised environment of the Gaertnerei Figure 3.

The five male refugees from Mali were eager to talk about their reasons for fleeing their home country, their perilous journey to Europe via stays in several transition camps along the way, and what they hoped for in a country that allowed them to stay but is yet to decide on their refugee status. What the students took away from these often confronting conversations due to the emotions expressed was the refugees' distinct experience of living in a parallel society, distanced from the residents in their neighborhood by social 


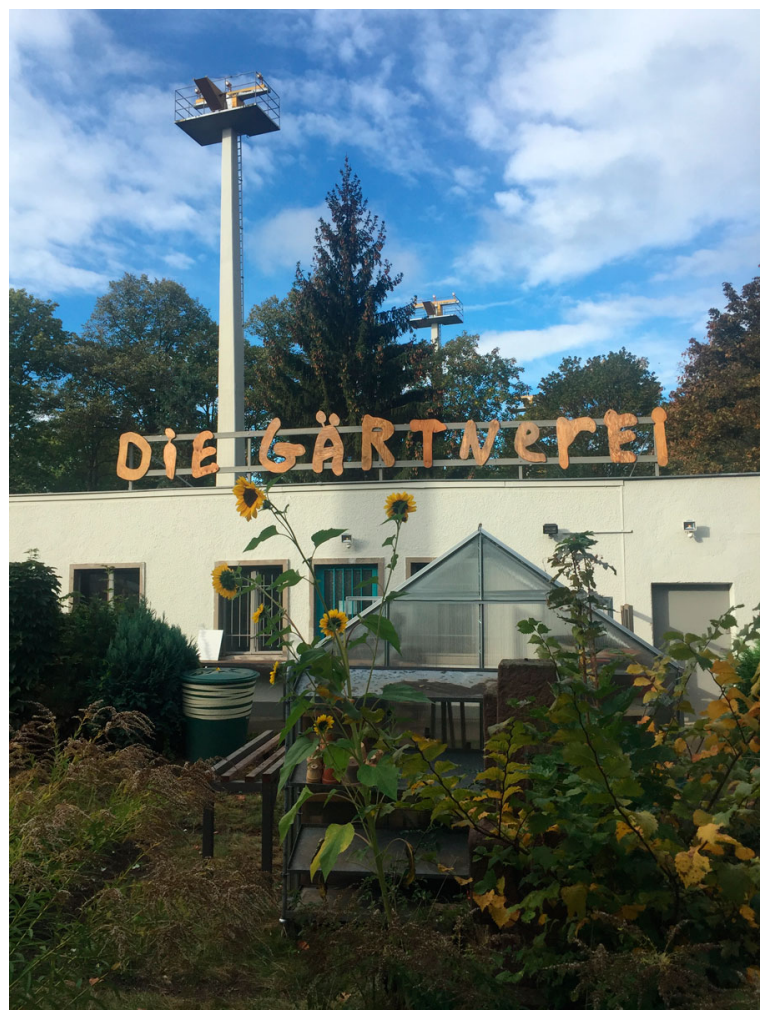

Figure 2. Live Conditions!, Gaertnerei Co-op Campus Berlin 2015, Photo: raumlaborberlin.

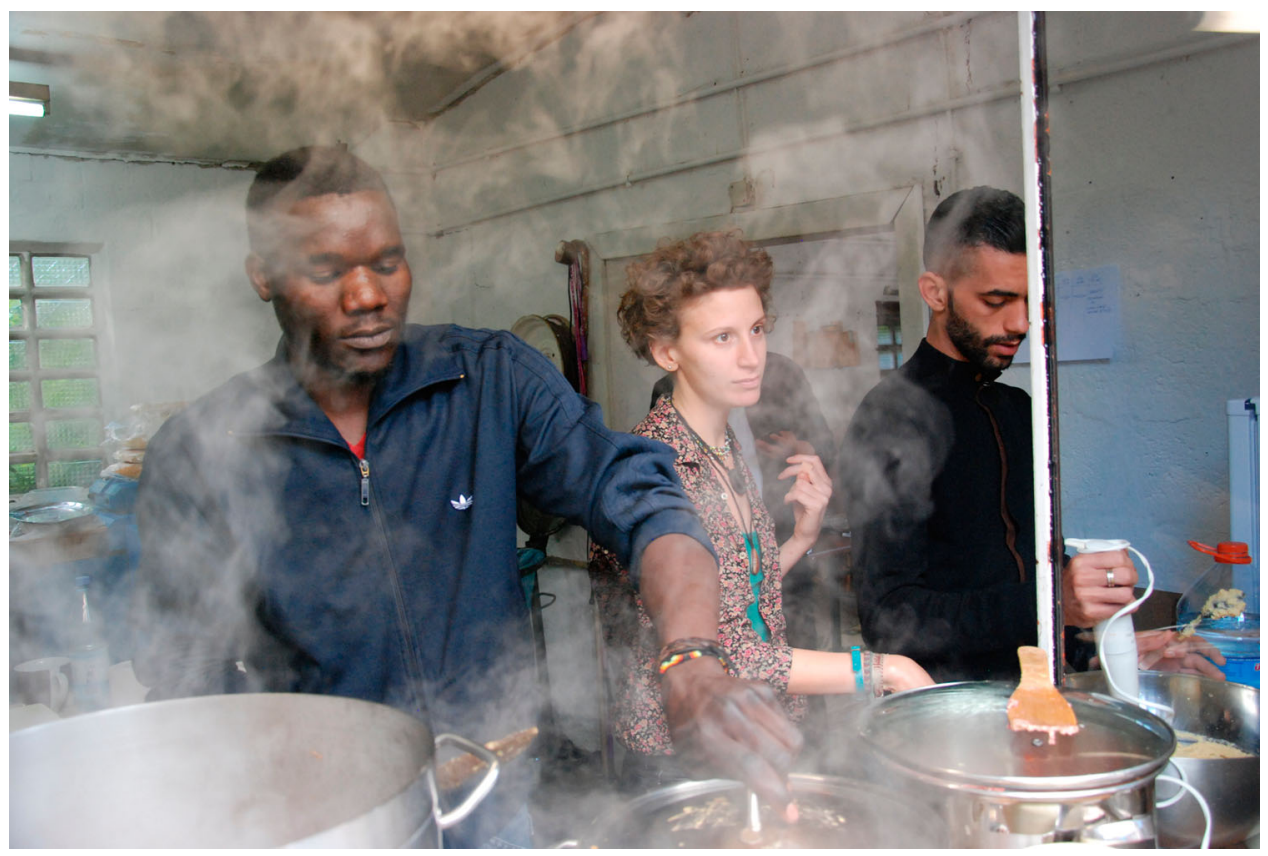

Figure 3. Live Conditions!, Communal Cooking, Gaertnerei Co-op Campus Berlin 2015, Photo: raumlaborberlin. 
status, language and the denial of freedom to travel outside of their designated location. We took the concept of the refugee experiencing their living situation as that of existing in a parallel society as the first design task to be completed in the remaining two days of the first week in Berlin. Students were asked to develop a utopic living environment for refugees that acknowledged the parallel worlds of resident and refugee while searching for ways to subversively dissolve these into a communal way of living. Narrative architectures and utopic design propositions of iconic 1960s and 1970s radical Italian architecture groups such as Archizoom and Superstudio who designed from scenarios rather than from pragmatic briefs served as inspiration for the students' graphic language and imagination. Students were asked to translate the refugees' individual experiences into an architectural ensemble while considering the city as a stage in which multiple narratives occur, and parallel lives are played out, explored and transgressed. Parasitic architectures were amongst the most prevalent designs that resulted from our brief - architectures where refugees participated in existing basic infrastructures, nesting unseen in existing residential buildings. Other designs looked at communal superstructures built by residents and refugees alike that would develop over time. All projects were termed spatial performances, performed by refugees and residents, sometimes together but more commonly existing next to one another Figure 4.

In studio week two in Dessau, students moved into accommodation in the Prellerhaus where the monastic living cells designed by Gropius are unchanged due to the Bauhaus' World Heritage Status, and bathrooms and tea kitchens are shared. With the Prellerhaus located adjacent to the former school building, students relived the historic Bauhaus

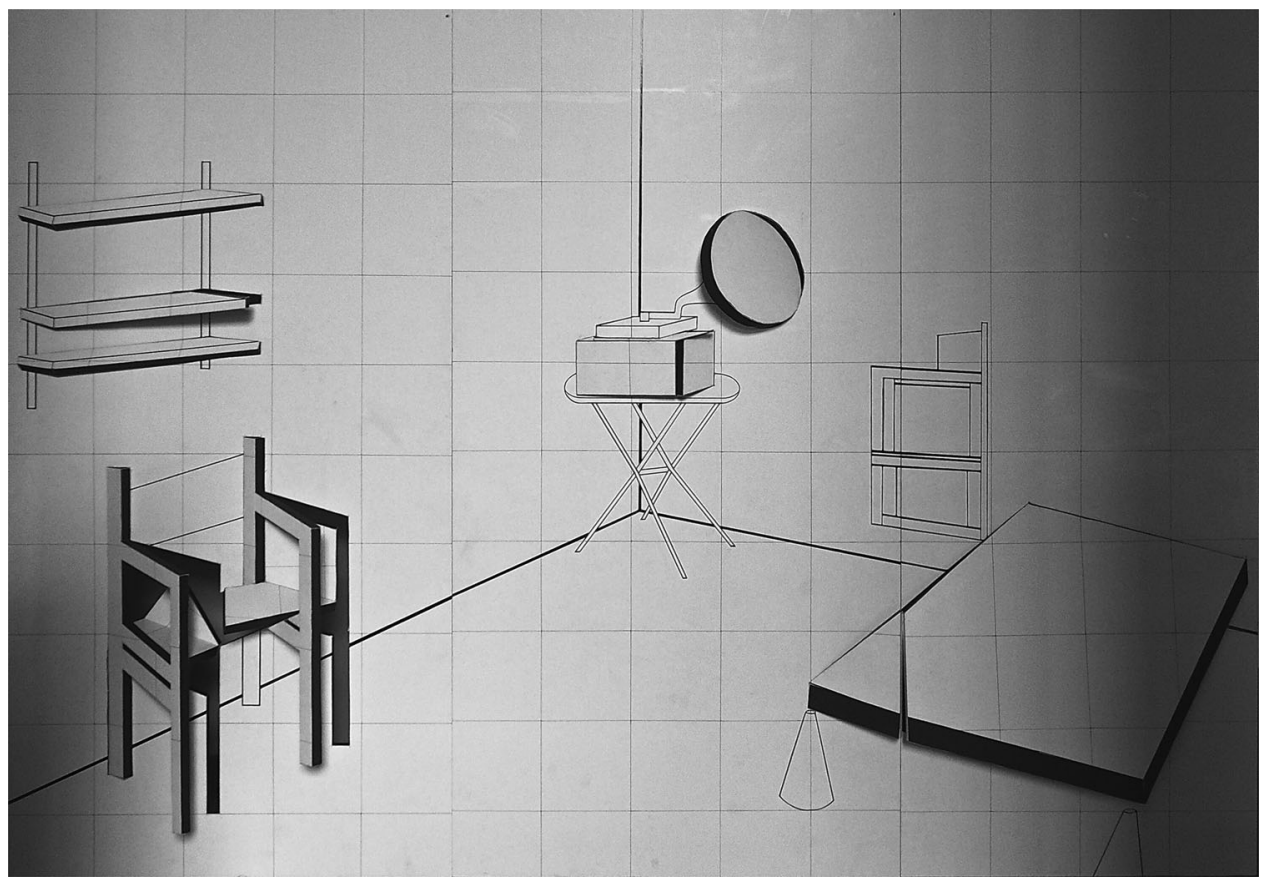

Figure 4. Live Conditions! Student Work, Hannes Meyer's Co-op. Interieur (1926) reimagined 2015. Photo: Yvonne Tenschert. 
experience of living, eating and working together in a spirit of experimentation. In this second phase of the studio, the 'making' aspect came to the fore and students were presented with Meyer's Co-op. Interieur and asked to reimagine his standard environment for minimal living as shown in the Interieur image before the background of their previous designs of deliberate and clandestine co-living between residents and refugees and their conversations with the group of refugees at the Berlin Gaertnerei. Their interiors had to be, as was Meyer's, full-scale and fully built, to be then presented as single photographs Figure 5.

The scenographic aspect, so evident in Meyer's original, reoccurred in each of the group works presented irrespective of the materiality chosen that ranged from fabric to cardboard to built wireframe objects and plywood. Each interior appeared to be awaiting its protagonist who would start the gramophone, sleep in the bed, take the folding chair off the wall and offer a seat to their guest, choose a spice to give aroma to a cooked meal. At the same time, the austerity of the cornered space, the absence of decorative elements, the apparent hardness of bed and chair meant that this was not a space of lingering but rather of transience and, if anything, of an enforced stay.

Reflecting on the shattering experiences, emotional conflicts and personal losses of the refugees, the students both understood Meyer's theoretical proposition but translated it spatially into an emotional, scenographic landscape. To the curators at Bauhaus who had just opened an exhibition on Hannes Meyer's work, the student works were astounding in their emotionality, expressed in the form of what we came to describe as scenographies of loneliness but also in the rigor with which they analyzed Meyer's original and rebuilt it in scale and exactly the same angle perspective and complete with all the domestic props of the original yet of the 'now' and far removed from a reenactment Figure 6.

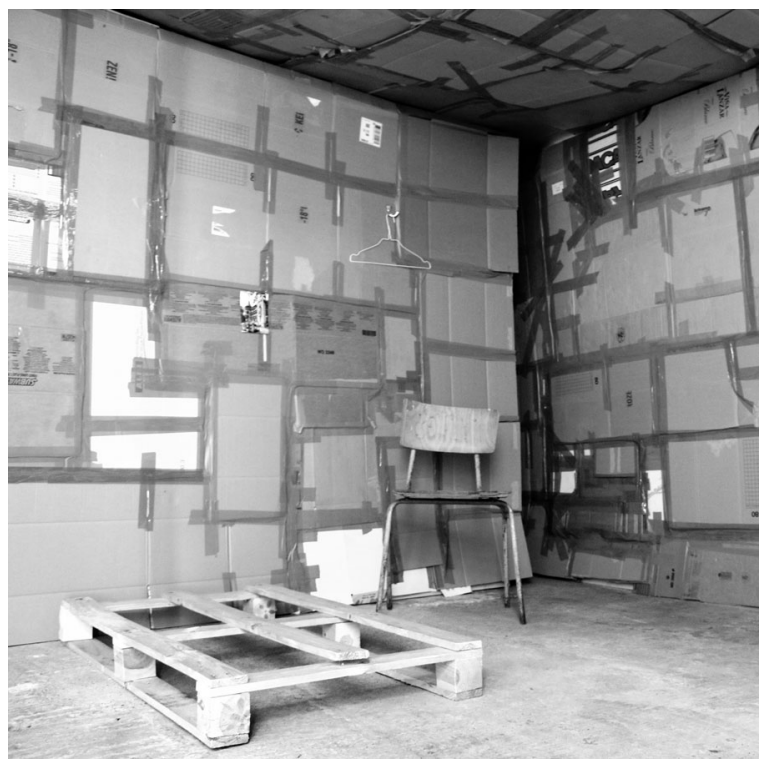

Figure 5. Live Conditions! Student Work, Hannes Meyer's Co-op. Interieur (1926) reimagined 2015. Photo: Yvonne Tenschert. 


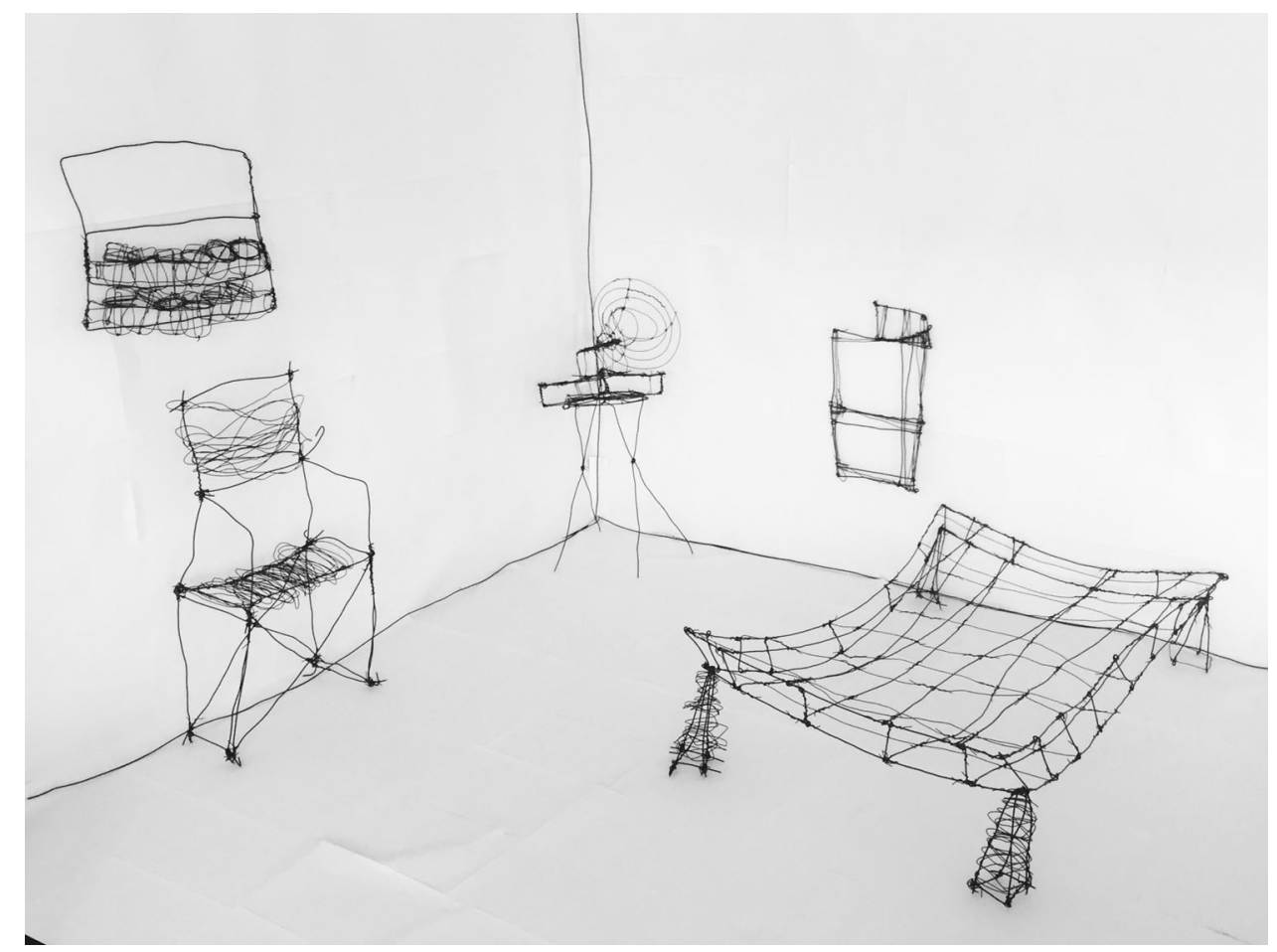

Figure 6. Live Conditions! Student Work, Hannes Meyer's Co-op. Interieur (1926) reimagined 2015. Photo: Yvonne Tenschert.

\section{Radical hospitality/movement (2016)}

As in the year before, the 2016 Bauhaus Open Studio juxtaposed aspects of the design history of the Bauhaus Dessau with contemporary strategies, methods, and materials. With the refugee thematics still being a highly politically and emotionally charged topic, we interpreted the Bauhaus' 2016 annual motto 'movement' in the first instance simply as the movement of people and refined this broad term (in the light of a political and civic discourse that ranged from a call for open borders to calls to close national borders for refugees) towards spatial articulations of inclusion and exclusion, of doors, entrances and thresholds. A single, residential house that would help to conceptually scale down national debates to individual ones, and that at the same time operated as a shelter, with the opportunity to be opened to allow access and to be closed to disallow access at any time through the basic architectural elements of wall, door, and window, seemed to us the most evocative precedent for students to develop their spatial articulations. The majority of Bauhaus architecture in Dessau, however, was designed as ensembles of houses (Gropius' Siedlung Toerten from 1926 to 28 for instance) or apartment blocks (Meyer's Laubenganghaeuser from 1929 to 30) and even Gropius' individually specified master houses for the Bauhaus masters Klee, Kandinsky, Muche, Feininger, and for Gropius himself (1925-26) are positioned as an ensemble of one typology. An exception to this is the Steel House (Stahlhaus), built in 1926/27 in a unique collaboration between the young architect Richard Paulick and Paul Muche, head of the Bauhaus' 
weaving department from 1921 to 1926 . Built as an experimental prototype for mass-produced housing, this ninety square meters single-level residence is a steel frame construction on top of a concrete slab foundation. The Steel House was clad entirely in three millimeters steel that was insulated on the inside. With a color scheme of white, grey and black and its forbidding metal facade, windows, and doors, the Steel House was only moderately successful at the time and thus remained a singular prototype yet it has become one of the key examples of experimental modernist architecture Figure 7.

In the first week in Dessau, we asked students to research the Steel House through a site visit, taking photographs and drawing, and to develop a spatial intervention into the building. This intervention was to be designed in the light of the humanitarian and political background of the global refugee crisis and based on a critical engagement with Jacques Derrida's 1996 lectures, 'Foreigner Question: Coming from Abroad/from the Foreigner' and 'Step of hospitality/No hospitality', published together as 'On Hospitality' in 2000.

Typically, hospitality is referred to as the relationship between a guest and a host, wherein the host receives the guest with goodwill. It is the friendly and generous reception, the entertainment of guests or strangers and the basic principle of hospitality is probably its reciprocity. In contrast, however, Derrida defines hospitality as an asymmetric relationship between a host and a stranger and as an ambivalent figure between conditional and unconditional hospitality, or: rather, as an irreconcilable antinomy between two laws.

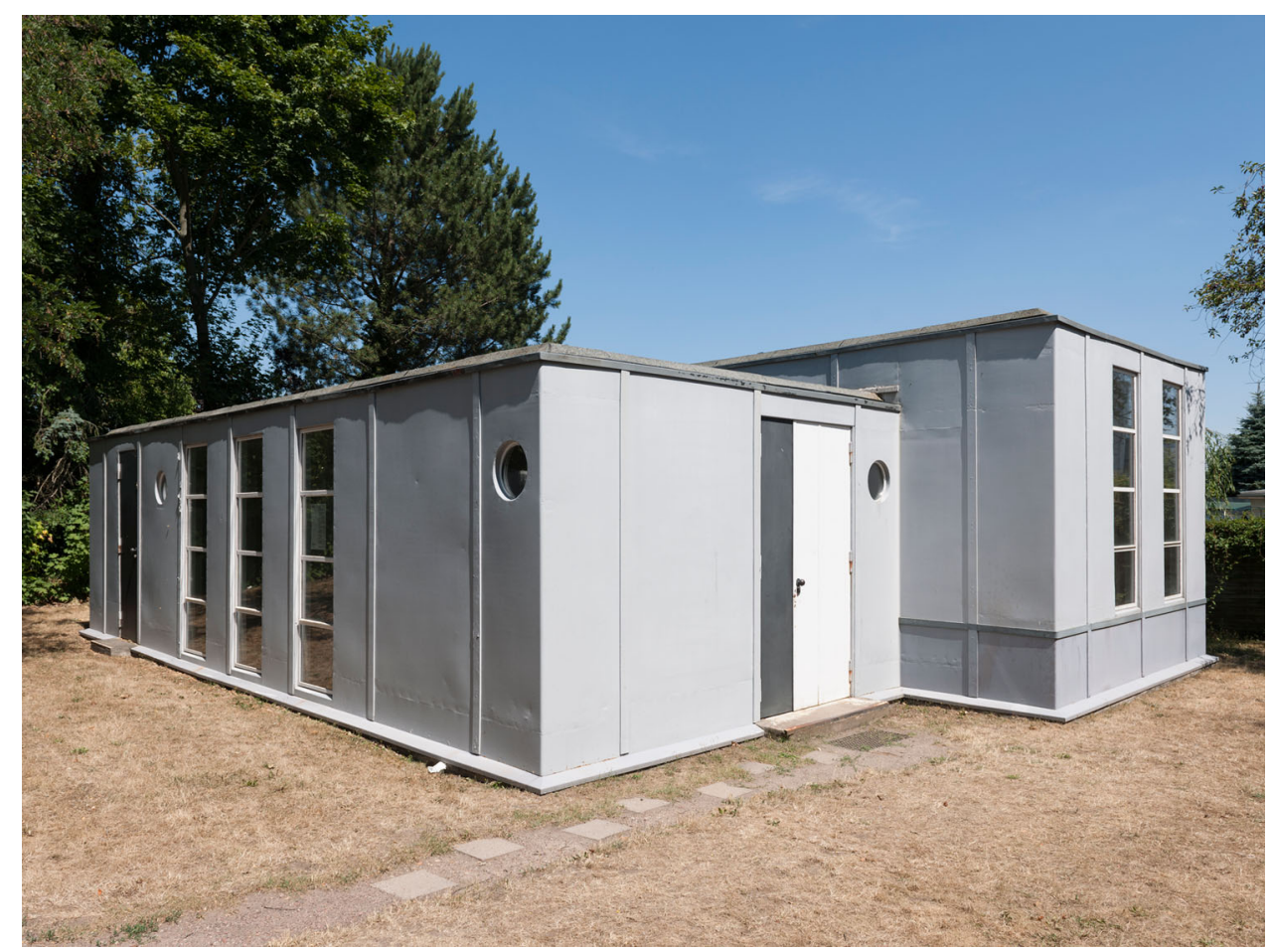

Figure 7. Steel House (Richard Paulick and Georg Muche 1926-27). Photo: Thomas Meyer, Ostkreuz 2018. 
The antinomy of hospitality irreconcilably opposes The Law, in its universal singularity, to a plurality that is not only a dispersal (laws in the plural), but a structured multiplicity, determined by a process of division and differentiation: by a number of laws that distribute their history and their anthropological geography differently. (Derrida 2000, 79)

To be hospitable in the first place, Derrida argues one must be able to open the doors of one's residence and thus must have a house, country or nation that one is the master of. Hospitality, and absolute hospitality at that, is thus inextricably linked to power and control in that the host must have a degree of control over the guests (strangers) in the understanding that a gesture of hospitality will necessarily transform into its violent opposite if the hosts' control is non-existent, is ignored or transgressed (Derrida 2000, 151-155). Students were equally intrigued by the appearance and materiality of the Steel House that they likened to a ship and to a military operational base of some kind and by the political, ethical and moral complexity of the notion of hospitality that Derrida unfolded. Students interpreted the architectural character of the experimental metal residence symbolically as being situated at the threshold between protective shelter and hostile fortress in conjunction with Derrida's concept of the necessarily conflicted relationship between host and guest/ stranger.

By the end of the first week, concept drawings of interventions that rearticulated conventional notions of door opening and closing mechanisms, steps, and layered walls that allowed for certain degrees of hospitality without opening one's private home, emerged

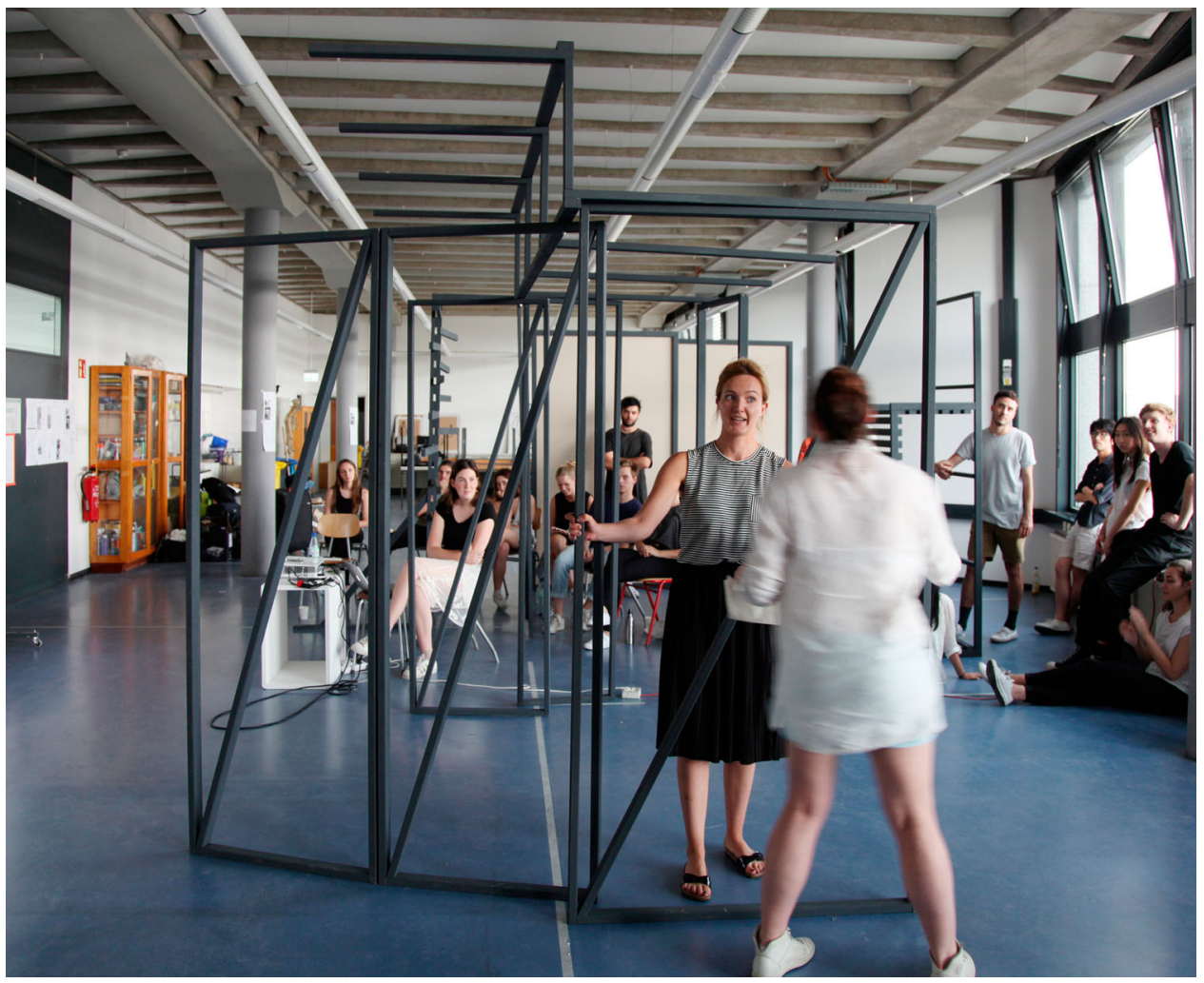

Figure 8. Radical Hospitality, reenactment of Georg Muche and Richard Paulick's Stahlhaus 1926-27 in five situations. Dessau, 2016, Photo: Stefanie Bürkle. 
amongst heated discussions arguing for and against Derrida's dictum of 'unconditional hospitality' Figure 8.

Week two occurred in the Visual Arts department of the Architecture Faculty of the Technical University Berlin in collaboration with Professor Stefanie Buerkle, Chair of the Department. There, in contrast to the clean, heritage-listed studios at Bauhaus Dessau, students were able to build their designs in full-scale detail constructions and not worry about potential damage to an architectural icon. The reality or: better, the realness of a full-scale detail construction of about four square meters per student group (6 groups of 2-4 students each) proved to be confronting to the students in several ways. Construction issues was one of them but more so it was the sudden grasp of the fact that they had on paper designed ambivalent gestures of hospitality that now in built form presented as doors that swung back to expel a stranger, or as double walls that kept the stranger hostage to the whim of the host, or as platforms that only allowed severely constricted possibilities to navigate, as stairs that were too high, or as ceilings that were too low. In a series of performative explorations guided by us, students were asked as a first step to operate their designs and articulated their experiences as users rather than as designers, and in a second step students were asked to operate a design other than their own and do the same. Insights from this exercise were verbally collected during a roundtable session and were used as constructive critique during the final optimization stage Figure 9.

During this two-tiered process of research, design and a subsequent build, perform/ test/perform, the studio explored Derrida's notion of (unconditional) hospitality that has inscribed in it a power relationship between host and stranger/guest. Through spatial design they tried to understand whether a concept of radical hospitality might have the power to resolve alienation, albeit only temporarily, and therefore bears the potential of an incremental inclusion of the other.

The resulting performative installations embodied the concept of hospitality as one of ambivalence in spatial gestures of simultaneous inclusion and exclusion. Muche and Paulick's Steel House was but a shadow in the final works yet its contemporary radicality shone through the installations, inspired by its uncompromising form and materiality the Steel House proved to be a productive provocation for the students to address contemporary issues of migration through a performative design strategy

\section{Constructing the commons, substance (2017)}

Led by the provocation whether and how current collaborative practices can create new urban spaces of commoning, the 2017 studio in collaboration with Markus Bader, Professor of Architecture at Berlin's University of the Arts (UdK) aimed at developing proposals for the future of the commons. To do this, the studio examined and deconstructed existing structures and artistic as well as theoretical positions of the commons and by constructing a real utopia based on a core understanding of space as an agency of the commons. It asked as to the relevance of the new commons before the background of the 'sharing economy'. It proposed that if the term 'sharing' has become a key term for an economy based on capitalist principles, the meaning of sharing has radically changed. The studio asked whether there are spheres beyond those of the market (economy) that allow us to shape our living environment. To do so, the studio focused on existing urban and 


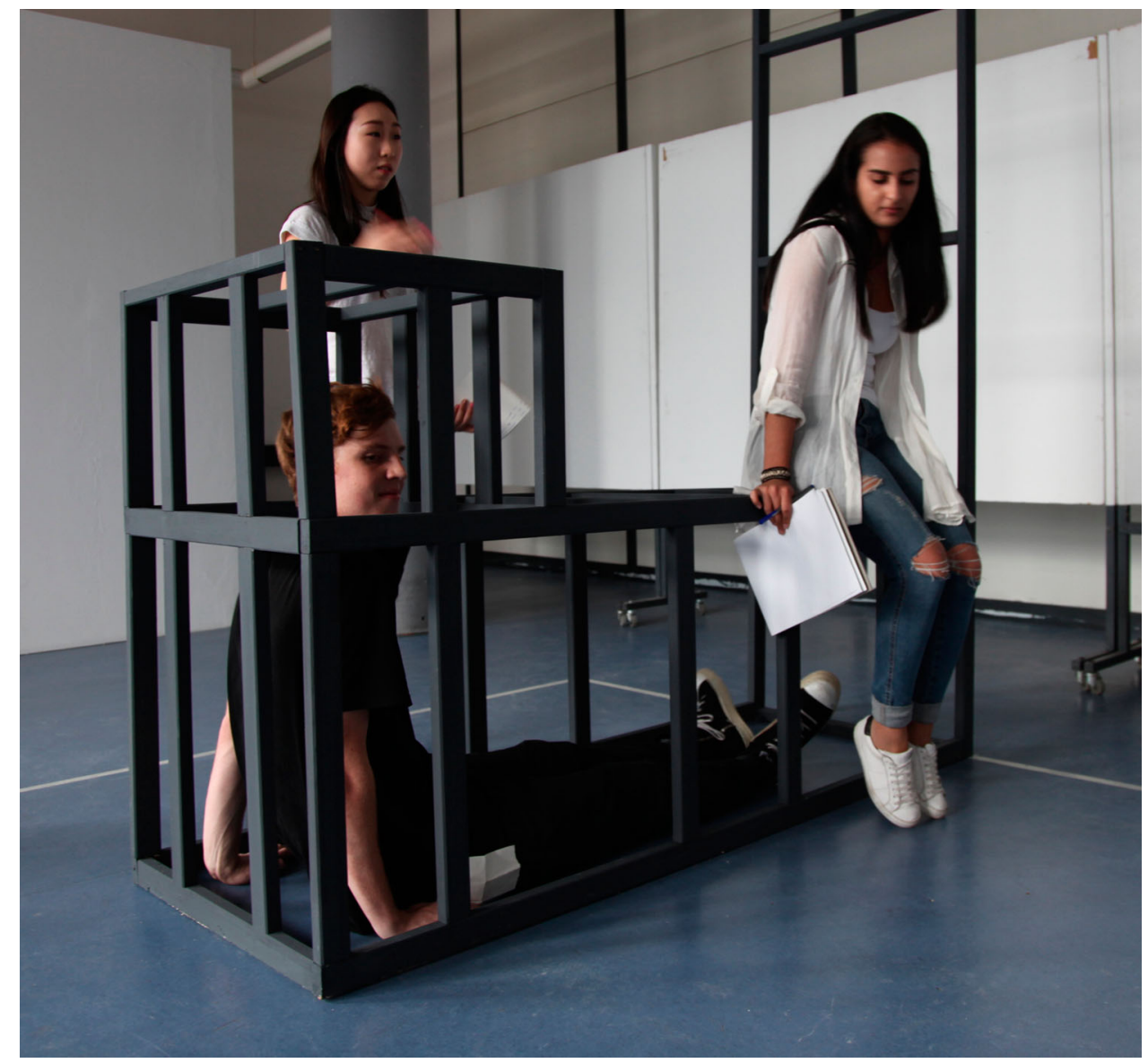

Figure 9. Radical Hospitality, reenactment of Georg Muche and Richard Paulick's Stahlhaus 1926-27 in five situations. Dessau, 2016, Photo: Stefanie Bürkle.

spatial models and scanned the basic conditions for commons and commoning to emerge and to thrive sustainably. The studio's Bauhaus reference point was an unrealized design by Gropius for a boarding house ('Wohnhotel' in the German original) as the German contribution to the 1930 Werkbund exhibition in Paris, a spatial installation across five large exhibition spaces that were dedicated to Gropius' key topic of how to live in a ten storey boarding house. This design showed in the form of extant plans and the extant exhibition model Gropius' architectural vision of the future of housing and his outline of the social changes that were to enable this. Beginning and end point of the circular exhibition parcours designed by Gropius and generally regarded as the highlight of the German section, was the 1:1 representation of a communal space located in the visionary ten story boarding house Figure 10.

The heart of Gropius' boarding house or 'Wohnhotel' is a 'communal area with the elegant atmosphere of a modern club, without a trace of mandated collectivism, containing both collective and individual recreation activities...' (Jaeggi and Bauhaus-Archiv 2007) ${ }^{6}$ This communal area was designed as a multi-functional space for entertainment, sport and well-being, research and reading, in the form of a library, a coffee bar, dance 


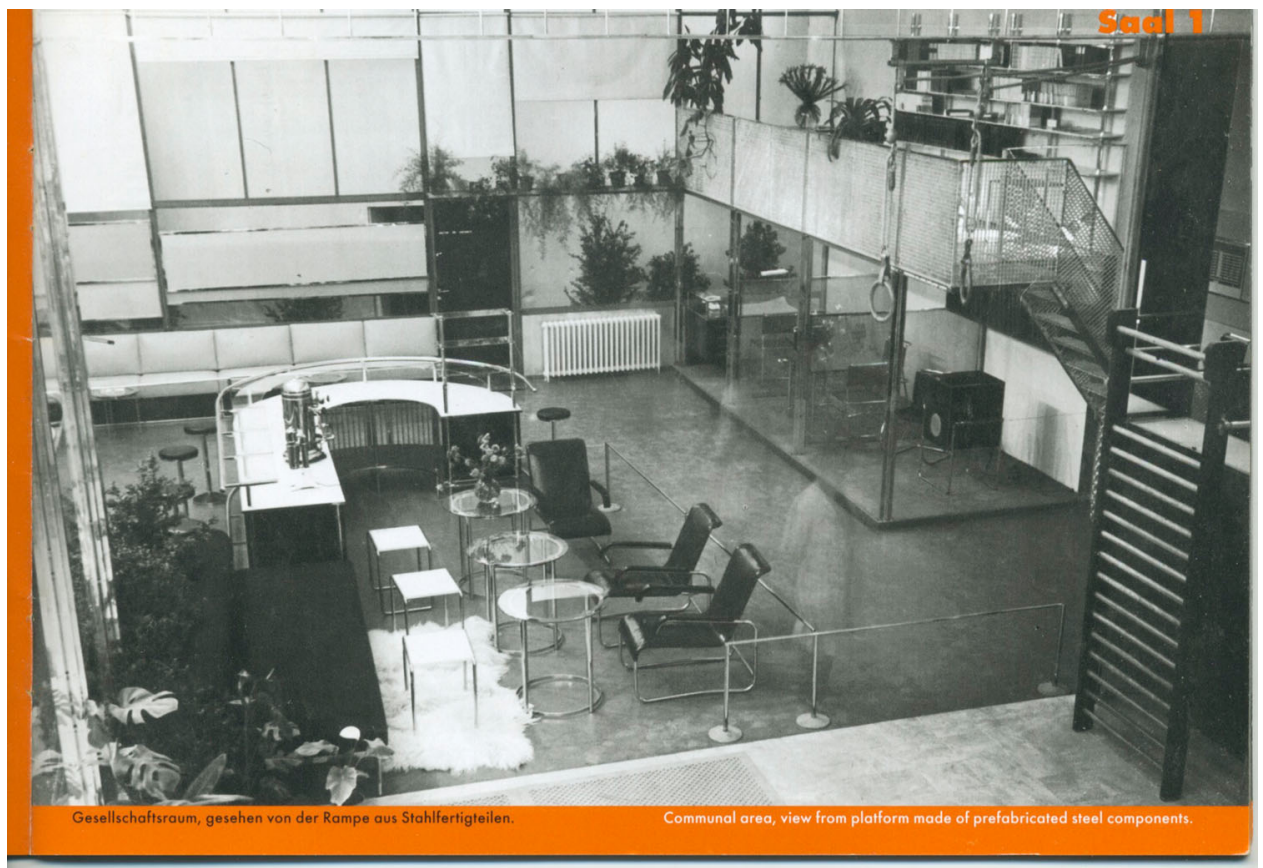

Figure 10. Wohnhotel (Gropius), Werkbundausstellung Paris 1930. [See endnote 6].

floor, swimming pool, and fitness area. This full-scale model was recreated by the Bauhaus Archive Berlin for the 100th anniversary of the German Werkbund. Photographs and plans of this 'space of commons' fuelled by Gropius' conviction that the future would see the distinct departure from the dominant single residence unit towards co-op organizations and an architectural and social focus on communal living. Our 'Substance' studio aimed to quite literally distill the substance of contemporary communal living through the historical lens of Gropius' vision, and while its beginning part was textual in the form of students' manifestos, the studio's outcome was the reimagination and rearticulation of Gropius' staged communal space in 1:1 model built rapidly and cheaply by the students as in the previous studios.

In the studio's first phase we asked the students to arrive at Bauhaus Dessau with a manifesto or mission statement that outlined their personal understanding of sharing in the age of Uberization and the gig economy. The students' statement was written in dialogue with the reading of 'On the Commons' (Anarchitektur 07/2010). ${ }^{7}$ In a second step, Gropius' boarding house was explored through the lens of spatial concepts of sharing and living together by analyzing not only his architectural language but also by looking at its social and political implications. In a third step, still in the first week of the studio in Dessau, students translated their findings by constructing situations of commons that bear relevance for contemporary and future living through diagrams, collages, drawings, and text. These were structured according to five socio-spatial concepts: maintenance, space activation, appropriating space, spaces of transition and spaces of privacy Figure 11.

These theoretical concepts were explored in daily practice during the week as Mayer and Bader brought the iconic raumlabor truck that incorporates a mobile kitchen to 


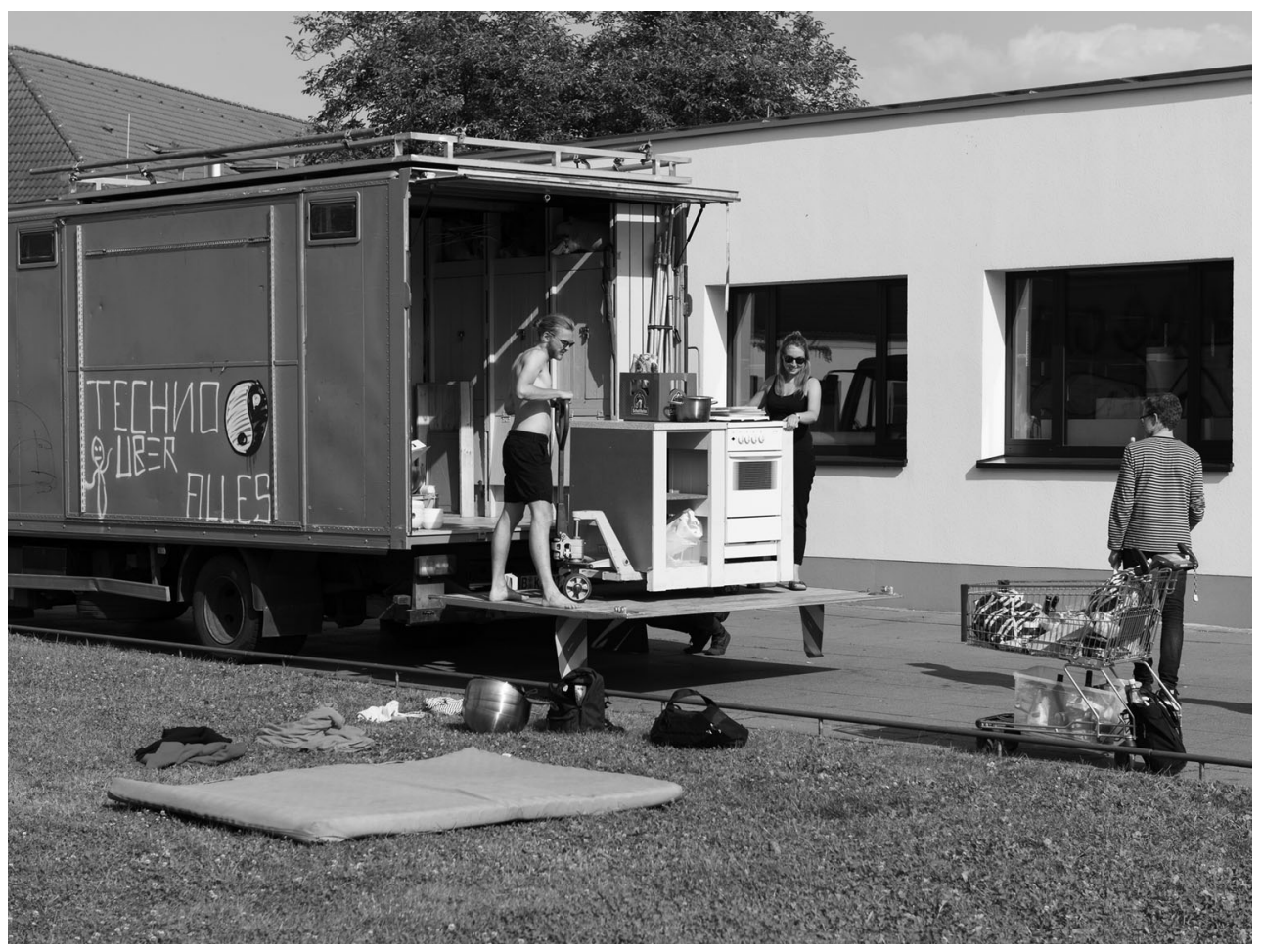

Figure 11. Constructing the Commons, raumlabor truck, Dessau 2017, Photo: Markus Bader.

Dessau. The vehicle remained parked on the lawn of the Bauhaus complex. Students shopped, cooked, ate and cleaned up in a self-organized fashion thus performing contemporary practices of commoning before the background of the historic Bauhaus practices and Gropius' historic vision of the future. The students' daily practices of cooperation and co-production in a contemporary appropriation of one of the main premises of the Bauhaus spirit of living and working together were seen by the many visitors to the Bauhaus in that week and reactivated the museum space to a performative space of action. Significantly from a pedagogical perspective, the performance of everyday domestic actions in our studio context of historical research and contemporary reimagination of Bauhaus precedents meant that students were able to experience the potential of the commons rather than developing a merely conceptual premise and speculative design. The first week ended with students' presentations of hypotheses and design questions rather than solutions for collective forms of housing for possible futures, and these became the entrance point for the second studio week in a temporary studio located at the Berlin site which itself is a temporary resistant structure searching for hybrid concepts of commoning a dormant building with a socialist past for present and future use Figure 12.

The concept of the commons is an optimistic opposition to capitalist society, a grounded vision embedded in Marxist thinking and vocabulary, focusing on the potential of already existing struggles and practices ('On the Commons', AnArchitektur 07/2010: 3).

Throughout the Bauhaus studios, the central material is not matter, but it is rather the experimental construction of situations to help articulate issues more precisely and to test these interactively with bodily engagement at full scale. In the case of 'Constructing the 


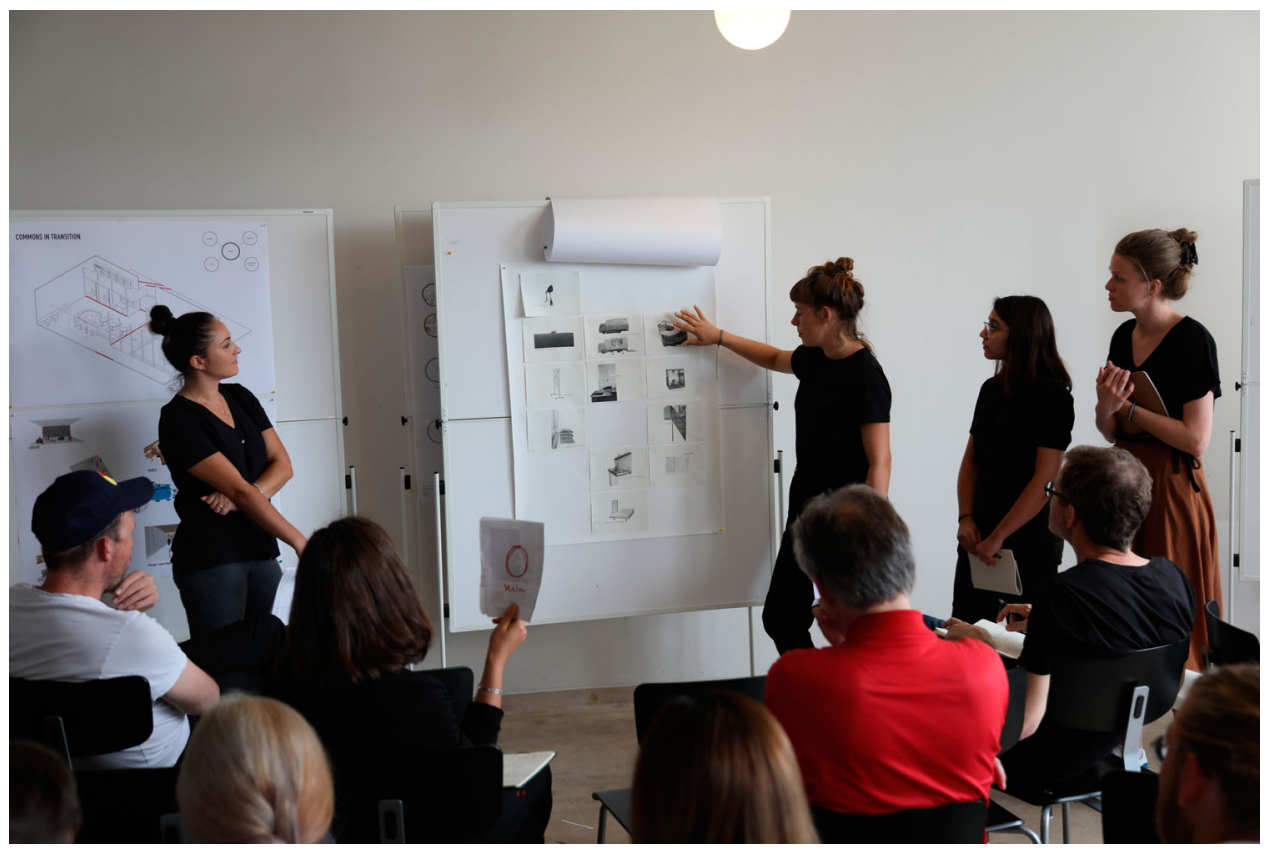

Figure 12. Constructing the Commons, Student Presentation of re-imagined Gropius' Wohnhotel, Dessau 2017, Photo: Christof Mayer.

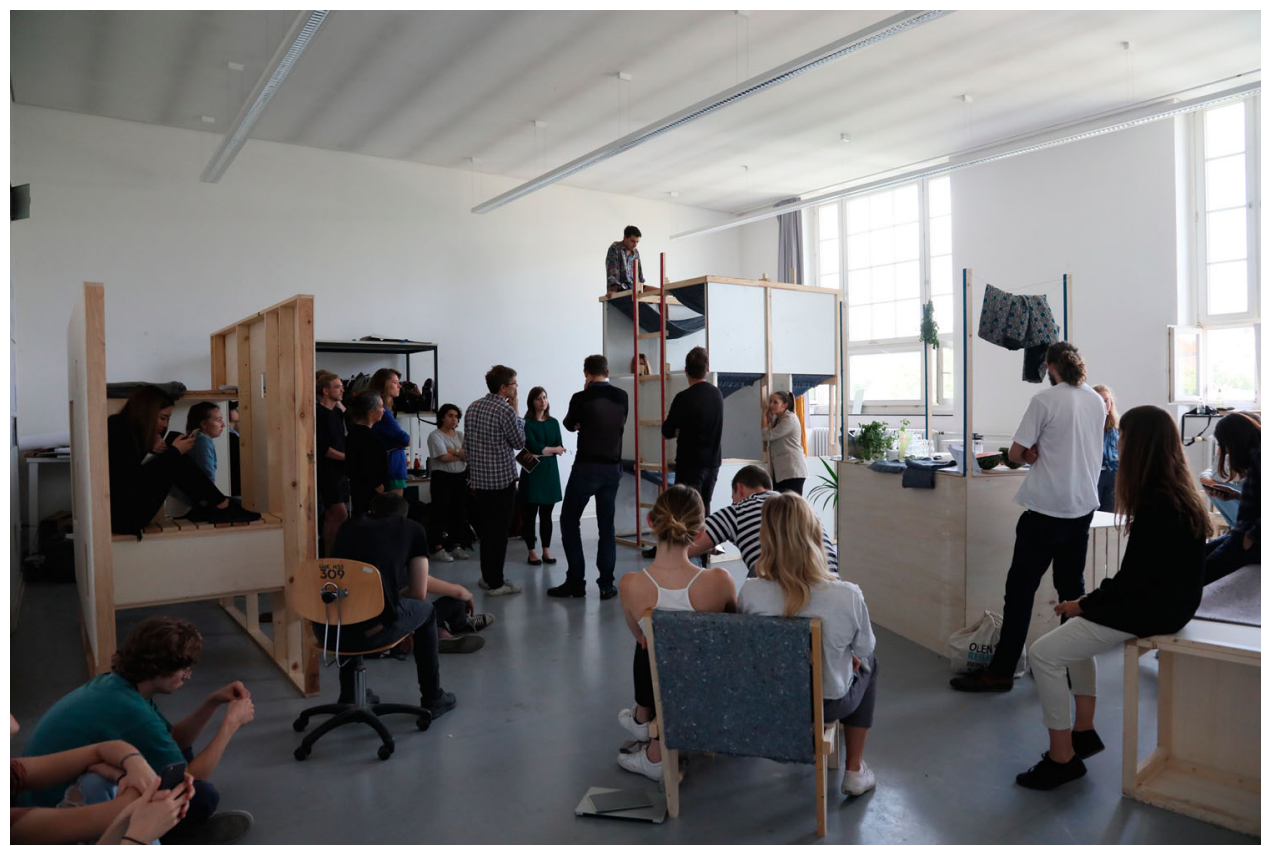

Figure 13. Constructing the Commons, Re-enactment of Gropius' Wohnhotel, Berlin 2017, Photo: Markus Bader. 
Commons', studio participants built their hypotheses as contemporary re-enactments of the 1930 German Werkbund exhibition in Paris Figure 13.

Their site however, was not the Paris exhibition space but rather the Berlin House of the Statistics, a highrise building complex from the late 1960s architectural style of New Objectivism in the former east part of the city. An initiative of artists and architects supported by the Berlin Capital City Cultural Fund have been collaborating on a multifunctional user concept that comprises living, working, and sites for cultural production and creative industries. By taking the House of the Statistics as the case study and site, students were asked to realize their propositional designs developed in Dessau as future hybrid structures, as built structures. As in Dessau, the students worked in full view of the public in the temporary shopfront-type studios of the Academy of Collaboration (Akademie der ZUsammenKUNFT in the German original, the capitals ZU and KUNFT spell ZUKUNFT (future)) constructing performatively an installation based on their contact with the material - the physical material as well as the discursive material developed through presentation and critique throughout the two studio weeks

\section{What futures? standard (2018)/conclusion}

In many respects, What Futures?, the last of the four collaborations with the Bauhaus Dessau, was conceptualized as the most open-ended studio of the series that would posit the question of how new knowledge and new forms of learning can be supported, fostered or even provoked by new architectures. We asked students to arrive in Dessau with a reflection on their own experiences of architectural and design education about the spaces they themselves were studying in. We anchored the annual theme, Standards, in the building of the Bauhaus Dessau itself and asked the students to 'read' the building together with Gropius' 1919 Weimar 'Bauhaus Manifesto and Program' and to map and to analyze building and manifesto in direct and tangible relation to each other. In the Manifesto, Gropius lays out his vision for this new place of research and practice and uses the image of a building as the analogy for a holistic pedagogy.

The ultimate aim of all visual arts is the complete building! To embellish buildings was once the noblest function of the fine arts; they were the indispensable components of the great architecture. Today the arts exist in isolation, from which they can be rescued only through the conscious, co-operative effort of all craftsmen. Architects, painters, and sculptors must recognize anew and learn to grasp the composite character of a building both as an entity and in its separate parts. Only then will their work be imbued with the architectonic spirit which it has lost as 'salon art.'

... They must be merged once more with the workshop. http://bauhausmanifesto.com/

The Dessau Bauhaus Academy, an interdisciplinary postgraduate and summer school program located in the former metal workshops of the Bauhaus, supports Gropius' comparison and states:

The Bauhaus building in Dessau is a built manifestation of the design school's curriculum (Bauhaus Academy 2018). https://www.bauhaus-dessau.de/education-5.html.

We asked the students to examine the notion of the building as a built manifestation of the Bauhaus' curriculum and to diagram their findings in the form of performative research that seeks to embody the experience of architecture through performance and movement Figure 14. 


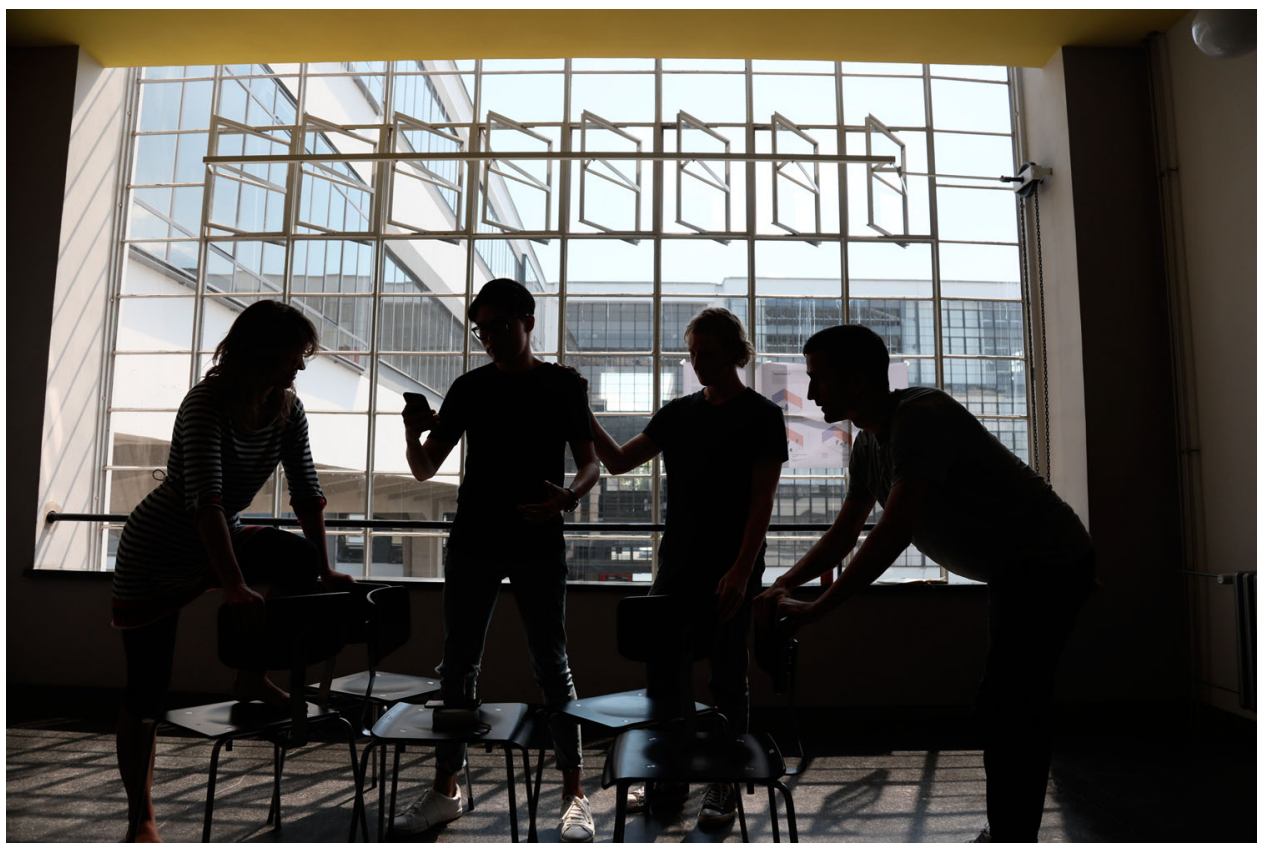

Figure 14. What Futures?, Students performing keywords inspired by Gropius' Manifesto, Dessau 2018, Photo: Christof Mayer.

Students explored the entire building in groups on the grounds of keywords they had chosen such as threshold, imagination, tranparency, collaboration and workshop. In a second step they used the keywords to develop a speculative scenario about the Bauhaus as an environment for learning. In the first instance, students were intimidated by the formality and rigidity of the building and furthermore felt at a loss not knowing whether to critique the building (which they felt they did not know how to do and did not dare) or to find analogies between Gropius' confident text and the museal space of the Bauhaus. Opting for the latter, the students' performative research discovered connective axes, perspectives, and materialities that enabled and supported the interdisciplinarity and the unity between art and technology that Gropius evoked so passionately in his manifesto. Students felt relieved, and indeed almost 'liberated' (they said), once the design dominance of the Bauhaus Dessau was left behind and the group traveled to Berlin to participate in the so-called 'Floating University' and to explore its spatial setting as a social and architectural proposition for a new practice of learning with new protocols, through the articulation of their own manifestos Figure 15.

Instigated and designed by raumlaborberlin, the temporary structure set onto the wetlands in the Tempelhof rainwater basin operated throughout 2018 as a 'laboratory for collective, experimental learning, knowledge transfer and the formation of transdisciplinary networks to challenge routines and habits of urban practices and as an inner city offshore' (raumlaborberlin 2018). Twenty universities participated in lectures, workshops and design studios to develop and perform spatial processes that are often kept separated, 


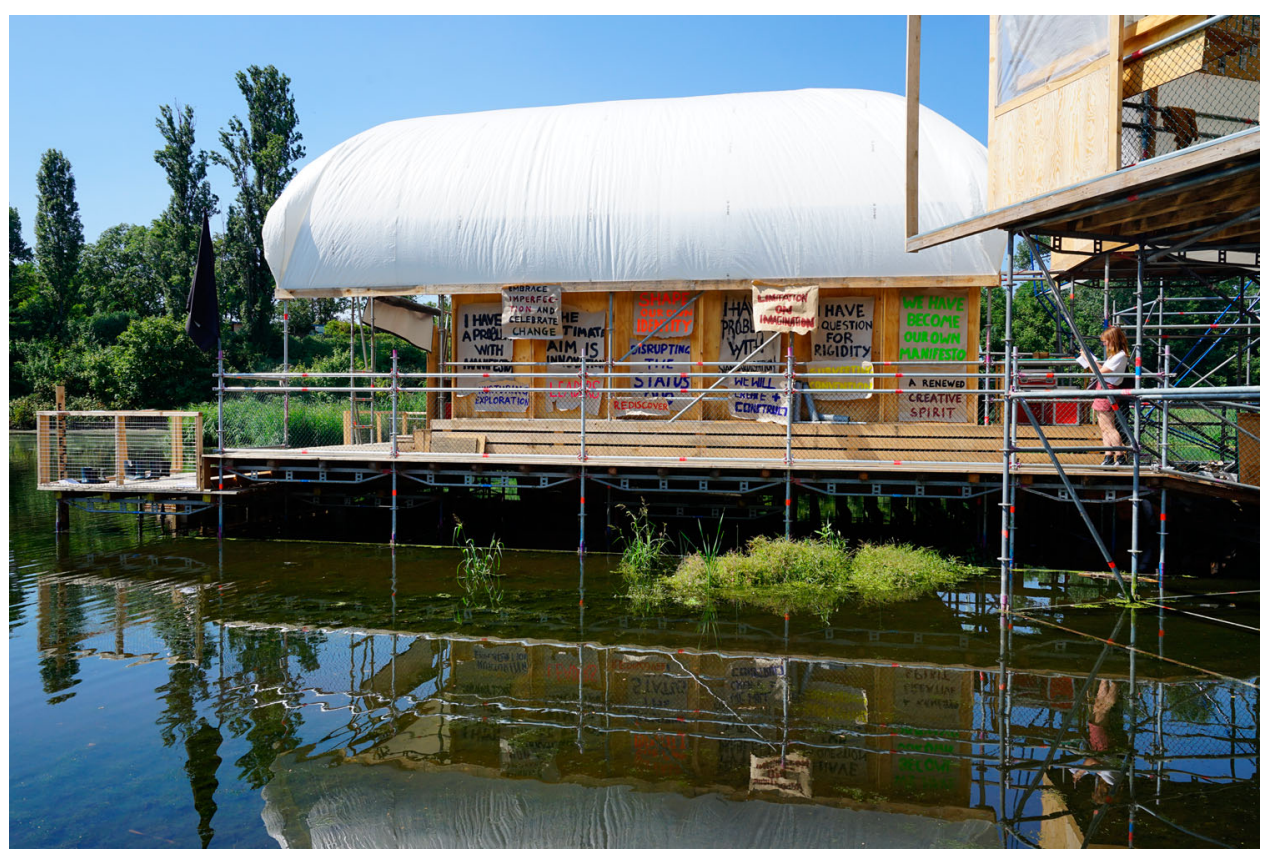

Figure 15. What Futures?, Floating University Structure, Berlin 2018, Photo: Markus Bader.

the kitchen and the study, the bar and the auditorium, the hot tub and the library, the laboratory and the street, the university and the park. This movement brings thought and practice together. How can we capture it? Name it?. (www.floatinguniversity.org/de)

The creative freedom such a venture brings with it was initially easily embraced by our student group. Soon after, though, a restlessness spread amongst the group that sprang from not knowing what to do and not knowing how to go about initiating one's brief. The brief existed, however, and was revealed at that very moment when things looked like they would collapse and the group would 'turn off.' Students were asked to overwrite Gropius' manifesto with their own words - wishes, utopias and ideas. They did so, critically, and in doing so, they challenged the genre of the manifesto itself:

I have a problem with manifestos. I have a question for rigidity. Where is the flexibility in a didactic text. A concrete representation of a moment in time. Embodying a legacy is a faulted paradigm. I have a problem with standardisation. Its limitation on creative imagination. The ultimate aim is innovation and with experimentation fluidity can flourish. We must embrace imperfection and celebrate change. Nurturing exploration through educational exchange. We must acknowledge legacy however shape our own identity and through playful collaboration we will create and construct a new future and these futures will embody a renewed creative spirit that values sustainability embedded within its leaders. Let these leaders guide themselves and support each other using their space to rediscover. Distrusting the status quo we've become our own manifesto. (Blackmore, Meyerowitz, Storay, Cho, Jahnsen $2018 \mathrm{np}$ ) Figure 16.

In a final act, students performed their manifestos, clad in wearable architectures they had to design and construct themselves. These wearable architectures were to give a 


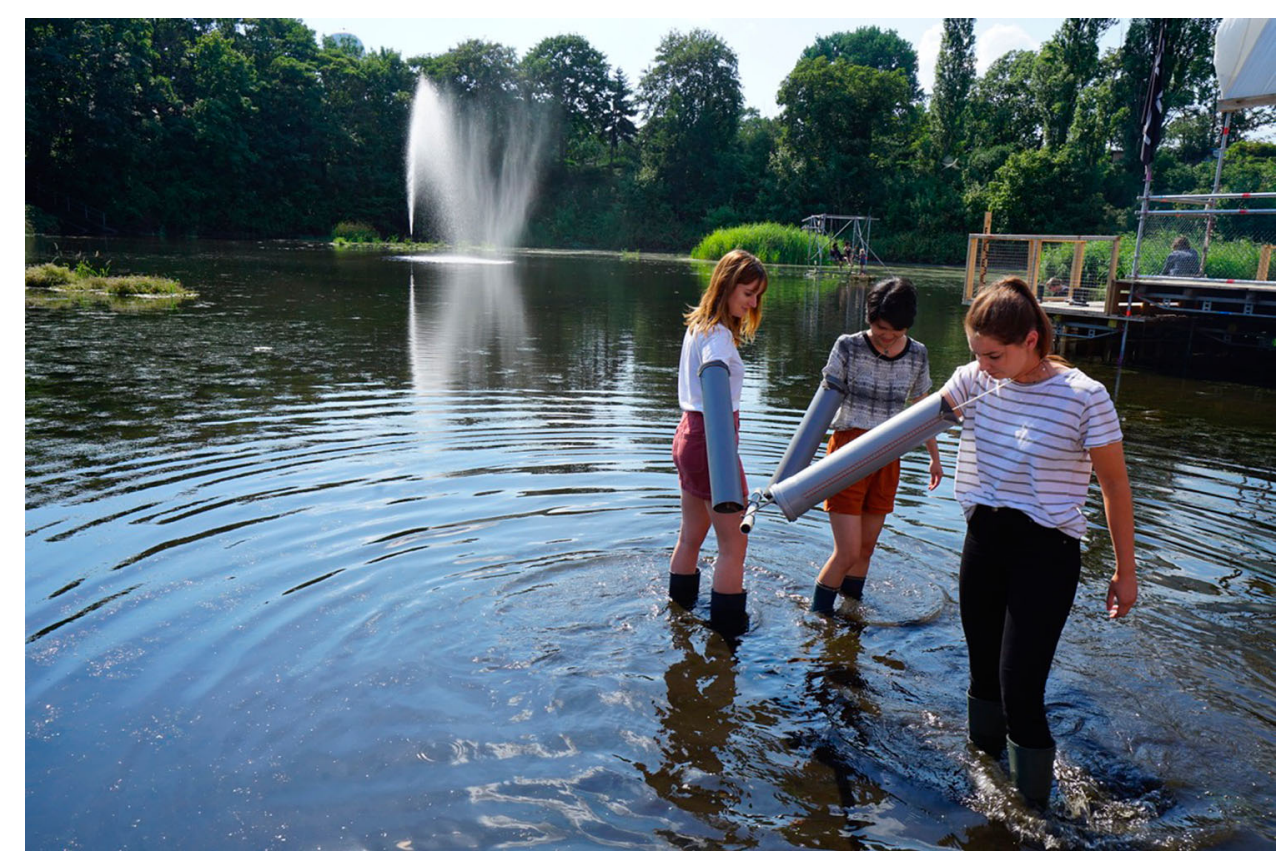

Figure 16. What Futures?, Students perform their manifesto in wearable architectures, Berlin 2018, Photo: Markus Bader.

sense, however abstract, of their ideal teaching and learning spaces' qualities, and the performances were as entertaining as they were also a fitting conclusion to our fouryear project. The students assigned a museal character to the Bauhaus building and could not easily identify with their student role in an architectural environment they regarded as stifling. Yet, by analyzing and mapping the building in a test situation where Gropius' manifesto was the measure, these young designers came to value and understand the significant layers Gropius worked as an architect, to present a building that strived to connect people from all disciplines regardless of background, gender and social class, to create something new for society. In the words of Michaela van Voorthuysen, one of the students:

Walter Gropius suggested that skill should come before art because one needs practical skills and knowledge in order to engage playfully with art. I believe that this fundamental idea of the Bauhaus is clearly linked to the structure of the Bauhaus building. Each room ... seems to be a workshop and enables social interaction. The staircase, the bridge, the canteen these are great spaces to develop new ideas (Van Voorthuysen 2018, 138).

The Floating University's aims are not that different from what van Voorthuysen recognises, namely that architecture can foster creative collaboration. A fundamental difference between Gropius' manifesto (and building) from the 1920s and the Floating University participants' manifestos (and buildings) from 2018 is that there is no singular master thinker or builder but rather a collective of architects, artists and designers stubbornly engaged in co-creation and performative research. 


\section{Notes}

1. The studio participants between 2015 and 2018 were undergraduate and postgraduate Interior Architecture and Architecture students from the University of Technology Sydney (UTS), the Technical University Berlin (TU) and the University of the Arts (UDK) Berlin.

2. See the yearly lantern party and procession in honor of Gropius' birthday on 18 May, the White Party from 1926 or the Metal Party from 1929, as well as lantern, dragon, Christmas or thematic parties such as the 1928 Bauhaus Band's 'beard, nose and heart party'.

3. raumlabor are a group of architects based in Berlin, Germany, who came together in 1999 in response to the rapid and unrestrained development of the city following the fall of the Berlin wall. Their playful approach critiques this dominant mode of architectural production, proposing instead temporary projects that transform the urban landscape through what they call 'urban prototypes'. Pneumatic structures, submarines made out of waste materials and halfserious projects such as building a mountain from the rubble produced through uncovering a buried canal are all part of their repertoire. This approach is not only used to critique official planning processes but also to influence them, such as the 'Kolorado Plan', which was developed for a local authority in Berlin. raumlabor proposed a long-term strategy for dealing with urban shrinkage that included small-scale interventions and involved local residents in the future of their neighourhood. Working in between the fields of architecture and public art, raumlabor, whose name means 'space laboratory', create projects based around events, performance and theater. Collaboration is a key part of their strategy with specialists including engineers, sociologists, local experts, ethnographers and citizens, being brought together around specific projects. Primarily working in public space, they see the task of the architect as highlighting problems rather than solving them. Their projects try to open up a space of communication and negotiation in which relations can be made and conflicts played out, and they acknowledge that for them architecture is first and foremost a social phenomenon. Placing themselves within the utopian tradition of 1960's architecture, including in particular the work of Yona Friedman, Buckminster Fuller and Haus-Rucker, raumlabor pre-empted this contemporary turn towards an experimental and reversible architecture also practiced by Urban Catalystand Exyzt. (http://www.spatialagency.net/database/how/subversion/ raumlabor)

4. The Swiss architect Hannes Meyer became well-known through his design of a communal housing estate in Freidorf, built between 1919 and 21. Meyer arrived at the Bauhaus as director of the newly established building department in 1927 and was appointed by Gropius as his successor and director in 1928. Meyer's political affiliation with Marxism led to the political radicalization of students and his slogan 'The people's needs instead of the need for luxury' went hand in hand with an erosion of the Bauhaus artistic departments in favor of vertical brigades. Growing disagreements with Gropius as to the future direction of the Bauhaus led to him being asked to resign from his position in order to protect the Bauhaus from political repercussions from the growing right political faction in Dessau and Germany as a whole. In 1930, the architect Ludwig Mies van der Rohe was to become Meyer's successor and the last director of the Bauhaus.

5. Meyer toured the propaganda theater co-op in 1924 in the framework of the internationale ausstellung des genossenschaftswesens und der sozialen wohlfahrtspflege (e.i.c.o.s) to Gent, Belgium where according to Meyer a total of 100 performances were seen by 15,000 spectators over the 3 month duration of the exhibition (Meyer and Bard 1924, 329).

6. Jaeggi, Annemarie, and Bauhaus-Archiv. Eds. 2007. Werkbundausstellung Paris 1930: Leben im Hochhaus. [Exhibition in the Bauhaus-Archive vom 21.11.2007-7.4.2008] = Werkbund exhibition Paris 1930. Berlin: Bauhaus-Archiv.

7. Janssen (2011).

\section{Disclosure statement}

No potential conflict of interest was reported by the authors. 


\section{References}

Bauhaus Academy. 2018. Accessed January 29, 2019. https://www.bauhaus-dessau.de/education-5. html.

Blackmore, Meyerowitz, Storay, Cho, Jahnsen. 2018. Student Portfolio Sydney 2018 (unpublished).

Derrida, Jacques. 2000. Of Hospitality: Anne Dufourmantelle Invites Jacques Derrida to Respond. Palo Alto: Stanford University Press.

Floating University. 2018. Accessed January 29, 2019. http://www.floatinguniversity.org/.

Floating University Berlin. Accessed January 29, 2019. http://raumlabor.net/floating-university-berlinan-offshore-campus-for-cities-in-transformation/.

Jaeggi, Annemarie and Bauhaus-Archiv, eds. 2007. Werkbundausstellung Paris 1930: Leben im Hochhaus [Exhibition in the Bauhaus-Archive vom 21.11.2007-7.4.2008] = Werkbund exhibition Paris 1930. Berlin: Bauhaus-Archiv.

Janssen, Joern. 2011. "An Architektur, 23: 'On the Commons' (July 2010)." The Journal of Architecture 16 (1), 149-154.

Meyer, Hannes. 1994. "The New World." In The Weimar Republic Sourcebook, edited by Anton Kaes, Martin Jay, and Edward Dimendberg. Berkeley, 445-448. Calif: University of California.

Meyer, Hannes and Jean Bard. 1924. "Das Theater CO-OP." In Das Werk: Architektur und Kunst 11 (1924): 329-332.

raumlabor. Accessed 26, February 2019. http://www.spatialagency.net/database/how/subversion/ raumlabor.

Van Voorthuysen, Michaela. 2018. "Learning From the Bauhaus." In Bauhaus No 10 Standard, edited by Stiftung Bauhaus Dessau, and Claudia Perren, 138-139. Dessau: Stiftung Bauhaus Dessau. 